\title{
The relationship between SNP rs895819 $(A>G)$ on miRNA-27a and the breast cancer in the Vietnamese population
}

- Nguyen Ba Hung Phong

- Tran Thi Hong Minh

- Nguyen Thi Ngoc Thanh

- Nguyen Thi Hue

University of Science, VNU-HCMC

(Received on $17^{\text {th }}$ November 2015, accepted on $2^{\text {nd }}$ December 2016)

\section{ABSTRACT}

Breast cancer $(B C)$, the most common type of cancer among women worldwide, is a polygenetic disease which is caused by the interaction of several genes. Understanding the genetic factors for early diagnosis of $B C$ is crucial to ensure the survival of $B C$ patients. MicroRNA 27a (miR-27a), an oncogenic miRNA, has been predicted to target on the tumor suppressor ZBTB10 that can regulate many processes of cell. Single nucleotide polymorphism (SNP) rs895819 alters the structure and function of miR-27a, which has been anticipated to reduce the risk of $B C$ in different populations such as German and Chinese. This study aimes to investigate the relationship between the existence of SNP rs895819 $(A>G)$ and the risk of $B C$ using the optimized high resolution melting (HRM) method. 106 BC samples and 117 healthy

\section{INTRODUCTION}

Breast cancer (BC) is the leading type of cancer in women worldwide. Excluding lung cancer, $\mathrm{BC}$ is the most common cause of cancer death in women [1]. In 2002, there were $1,383,500$ BC incidences and these caused 458,400 deaths worldwide [2]. Until 2012, $1,671,000$ new cases of $\mathrm{BC}$ in women were estimated, caused 522,000 deaths over the world samples were genotyped using an optimal HRM protocol then statistical analysis was applied to examine the relationship of the SNP. In the case group, the risk $G$ allele accounted for $36 \%$ while in the control group it took up $32 \%$. Statistic result revealed that $r s 895819(A>G)$ had no significant relationship with the breast cancer $(O R=1.119 ; P=0.46676)$ in given case-control samples. Although the SNP is significantly ralated with $B C$ in German or Chinese populations, it is not a potential marker for diagnosis in the Vietnamese population. Further studies investigating relationship between rs895819 (A>G) and breast cancer in the Vietnamese population is not recommended. In future, other SNPs should be investigated with the aim of identification efficient biomarker for early diagnosis of $B C$ in Vietnamese.
[3]. In Vietnam, the breast cancer incidence has increased significantly during the last decade, from a rate of 13.8 per 100,000 women in 2000 to 28.1 per 100,000 women in 2010 , with an estimated of 12,533 breast cancer cases in the country [4]

BC starts when there is a malignant tumor, a group of cancer cells, growing in the tissue of the 
breast. There are numerous risk factors that have been known to be the cause of BC including intrinsic factors (host genetic) and extrinsic factors (environmental factors). Although familial inherited genetic factors only account for $5-10 \%$ of BC cases, it is an essential factor in the prevention and early detection of $\mathrm{BC}$ [1]. Among the genetic factor, microRNAs (miRNA) and their polymorphisms recently have been investigated in the cancer research. MiRNA, a tiny, approximately 18-25 bases in length, noncoding piece of RNA, plays a significant role in the regulation of the gene expression [5]. The regulatory activity of miRNAs is based on their ability to bind to complimentary regions of their target messenger RNAs (mRNAs) to induce the translational repression or mRNA degradation. MiRNAs participate in many biological processes such as cell proliferation, differentiation, apoptosis and development. Any defection in activities of miRNAs can lead to improper function of these processes. Therefore, SNP, minute mutations that has enormous effects in miRNA activities, is a highly potential target for studies of cancer, including BC.

MiR-27a is an oncogenic miRNA located in the chromosome 19 (location 19q13.13, from nucleotide $13,836,440$ to $13,836,517 ; 78 \mathrm{bp}$ ). Its important role in the breast cancer development has been demonstrated by many studies [6-8]. The oncogenicity of miR-27a is its expression in cancer cell down-regulates the expression of ZBTB10 in the mRNA/protein level. ZBTB10 is a suppressor of many specific protein (Sp) transcription factors such as $\mathrm{Sp1}$, which induces the expression of the estrogen receptor (ER) and other Sp-dependent genes which are important for cell survival and angiogenesis such as vascular endothelial growth factor (VEGF), VEGF receptor 1 (VEGFR1), or VEGFR2. ER is an important protein in cells which has a role in the regulation of many processes in cells such as proliferation, apoptosis and cell cycle, supporting sustainability of cell. Dis-regulation of ER pathway can cause the dis-function of cells and may lead to cancer. Abnormally inhibited ZBTB10 causes overexpression of these Sp and Sp-dependent genes, and the overexpression of ER leads to the cancer development $[6,7,8]$ The SNP rs895819 is located in the terminal loop of pre-miR-27a. The alteration of the structure and function of miR-27a by this SNP can alter the ER pathway and finally affects the development of BC.

The effect of SNP rs895819 on the expression of $\mathrm{BC}$ has been investigated in many populations and these studies aforded contradictory results. In 2010 a study conducted on German women had confirmed that the rare $\mathrm{G}$ allele of the SNP had the protective effect against BC in the German population [9]. Later in 2013 a study carried out on Chinese population also yielded similar result [10]. However, a study performed on Italian population in 2012 was in contrast with those two studies by saying that the SNP rs895819 had no with BC [11]. The inconsistence in result of those studies has motivated us to carry out experiments to examine relationship between of the SNP to BC.

In this study, SNP rs895819 was screened on Vietnamese BC patients by HRM method. This method is based on PCR melting (dissociation) curve techniques and is supported by the innovative double-stranded DNA (dsDNA)binding dyes along with next-generation realtime PCR instrumentation and analysis software. The DNA is first amplified by normal three-steps PCR, then undergone a short melting step where analysis software works, in the aid of signal from DNA-binding dye, to figure out the unique melting pattern of the DNA strand in the form of melting curve, representing the genotype of the SNP.

\section{Trang 40}


This study was conducted to examine the relationship between the SNP rs895819 which located on miR-27a in Vietnamese population, which had not been studied before. MiR-27a and its SNP were chosen due to their ability to indirectly target to ER, which play an important role in the $\mathrm{BC}$ development. The study was accomplished by using an optimized high resolution melting (HRM) method.

\section{MATERIALS AND METHODS}

\section{Collecting samples and DNA extraction}

The interested population in this study was Vietnamese one. Blood samples were collected from patients with positive or negative clinical diagnosis for breast cancer in Oncology Hospital from 2011 to 2014. Samples included 106 BC cases and 117 healthy controls. All of the patients were given the consent forms to sign on. The collected blood was stored in tubes containing EDTA in $-20{ }^{\circ} \mathrm{C}$ for further use.

DNA from blood samples was extracted by salting-out method followed the protocol [12]. First white blood cells were isolated from the whole blood by centrifugation. The white blood cell was added with cell lysis buffer (TrisHCl 10 $\mathrm{mM}$, sucrose $11 \%, \mathrm{MgCl}_{2} 5 \mathrm{mM}$ and Triton $\mathrm{X} 1001 \%)$ to be lysed and released cellular components. Then the cell pellet was added with nuclei lysis buffer (TrisHCl $10 \mathrm{mM}$, SDS $1 \%$, EDTA $10 \mathrm{mM}$, sodium citrate $10 \mathrm{mM}$ ) to lyse the nuclei and release DNA. Then, the DNA was separated from other components and cell debris by adding $\mathrm{NaCl}(50 \mathrm{M})$ and absolute chloroform. The upper aqueous phase containing DNA was then transferred to a new eppendorf. The DNA was precipitated out of the solution by using absolute ethanol, followed by ethanol $70 \%$. The supernatant was discarded and the precipitated DNA was kept overnight for drying. Finally, the dried and clear DNA was dissolved in water and stored in $-20{ }^{\circ} \mathrm{C}$ for further use. After extraction, DNA samples measured the absorbance by a
NanoDrop 1000 Spectrophotometer (Thermo Scientific, USA). To be chosen for HRM analysis, the DNA sample must have the concentration of $10 \mathrm{ng} / \mathrm{ul}$ or higher and the purity (OD value A260/A280) is in the range of 1.6-1.9

\section{Development of HRM protocol for genotyping}

This study implemented the HRM technique in which typical three-step thermal cycles are followed by a short heating of PCR product to reach the melting temperature. During the time of rising the temperature, the sensor inside the instrument captures the change of florescence signal emitted by dsDNA-binding dye. The signal is analyzed by software ad visualized in the form of the melting curve which represents for three genotypes of the SNP. The detail of HRM principle and result visualization is shown in Figure 1.

The sequence of SNP rs895819 region on the miRNA-27a was identified using Gene Bank database. The sequence and other informations of this SNP could be obtained from the web page http://www.ncbi.nlm.nih.gov/projects/SNP/snp_r ef.cgi?rs=895819. As getting the SNP sequence, the primer design was carried out by the Primer3Plus online software (http://www.bioinformatics.nl/cgi-bin/primer3plus/primer3plus. cgi/). The parameters were set as: product size 80-150 bp, primer size 18-25 bp, primer Tm around $60-70{ }^{\circ} \mathrm{C}\left(65{ }^{\circ} \mathrm{C}\right.$ is the optimum). Then the chosen pairs of primer were given to BLAST (http://blast.ncbi.nlm.nih.gov/Blast.cgi) to check whether they were specific for the SNP sequence. Pairs of primer which had high specificity were then used to predict the HRM melting curve of their amplicons using the UmeltHet software (https://www.dna.utah.edu/hets/umh.php). The resolution was adjusted to "Very high $-0.1{ }^{\circ} \mathrm{C}$ " and other PCR components such as $\mathrm{Mono}^{+}, \mathrm{Mg}^{2+}$, DMSO concentration were also screened in order to create three distinct melting curves and peaks representing 3 genotypes of the SNP. Beside the 
primers for HRM analysis, an extra pair of primer for sequencing to confirm the genotypes of three positive control samples was also designed.
Primers and amplicons were described in Table 1.

Table 1. Primers for HRM analysis and sequencing

\begin{tabular}{|l|l|l|l|}
\hline Primer & Sequence & $\begin{array}{l}\text { Melting } \\
\text { temperature }\end{array}$ & $\begin{array}{l}\text { Amplicon } \\
\text { length }\end{array}$ \\
\hline HRM_Forward & 5'-GGCAAGGCCAGAGGAGGTGA-3'(20 bp) & $67.2^{\circ} \mathrm{C}$ & \multirow{2}{*}{$105 \mathrm{bp}$} \\
\cline { 1 - 2 } HRM_Reverse & 5'-GGCCTGAGGAGCAGGGCTTA-3'(20 bp) & $66.1^{0} \mathrm{C}$ & \\
\cline { 1 - 3 } Seq_Forward & 5'-AGTAGGCACGGGAGGCAGAG-3'(20 bp) & $64.1^{0} \mathrm{C}$ & \multirow{2}{*}{$303 \mathrm{bp}$} \\
\cline { 1 - 3 } Seq_Reverse & 5'-GGGGATGGGATTTGCTTCCT-3' $(20 \mathrm{bp})$ & $64.5^{\circ} \mathrm{C}$ & \\
\hline
\end{tabular}

The HRM optimization procedure was composed of three steps: initial optimization, determination of three control genotypes and final optimization. In the initial optimization step, we aimed to find out the condition of three factors annealing temperature (Ta), $\mathrm{MgCl}_{2}$ and DMSO concentration in which the HRM reaction yielded a good melting curve. To determine the optimal Ta, five PCR reactions with gradient annealing temperatures $\left(60-68{ }^{0} \mathrm{C}\right)$ were run using Eppendorf Mastercycler. The reagents included Toptaq Mastermix 1X, 0.2 $\mu \mathrm{M}$ each primer and $50 \mathrm{ng}$ DNA. For optimization of $\mathrm{MgCl}_{2}$ and DMSO concentrations, different concentrations of $\mathrm{MgCl}_{2}$ and DMSO were added to $10 \mu \mathrm{L}$ reaction mixture and tubes were placed in 96-well plate of LightCycler 96 thermocycler (Roche Diagnostics, Germany). The concentrations of $\mathrm{MgCl}_{2}$ and DMSO in this step were based on the prediction on UmeltHet. The reagents in the reactions included Light Cycler 480 Resolight Dye Mastermix 1X, 0.2 $\mu \mathrm{M}$ each primer HRM Forward/ HRM Reverse, $50 \mathrm{ng}$ DNA and adjusting concentrations of DMSO and $\mathrm{MgCl}_{2}$. Thermal cycles were set as the following: 5 minutes pre-incubation at $95{ }^{\circ} \mathrm{C}$ followed by 40 thermal cycles including 30 seconds denaturation at $95{ }^{\circ} \mathrm{C}, 30$ seconds annealing at $66{ }^{\circ} \mathrm{C}$ and 30 seconds extension at $72{ }^{\circ} \mathrm{C}$ for each cycle; and continued by high resolution melting step including 90 seconds at $95{ }^{\circ} \mathrm{C}$, then 60 seconds at $40{ }^{0} \mathrm{C}, 30$ seconds at $65{ }^{0} \mathrm{C}$ and gradually increasing temperature from 65 to $95{ }^{0} \mathrm{C}$. The process was ended by a hold cooling at $37{ }^{\circ} \mathrm{C}$

After having initial HRM protocol, few samples were applied in order to find out three control genotypes. Eight samples were run on HRM analysis and three distinct groups of melting curve, representing for three genotypes AA, AG and GG, were obtained. Random samples from each genotype were sequenced to confirm their exact genotype. The reagents for PCR reaction to prepare for sequencing included Toptaq Mastermix 1X, $0.2 \mu \mathrm{M}$ each primer Seq_Forward/ Seq_Reverse and 50 ng DNA sample. Finally we had three positive controls which represented the three genotypes of the SNP. As three positive controls were determined, optimization had to be conducted again in order to obtain the clustered and distinct melting curves of three controls together. The adjustment of the $\mathrm{MgCl}_{2}$ concentration was carried out one more time.

\section{Trang 42}



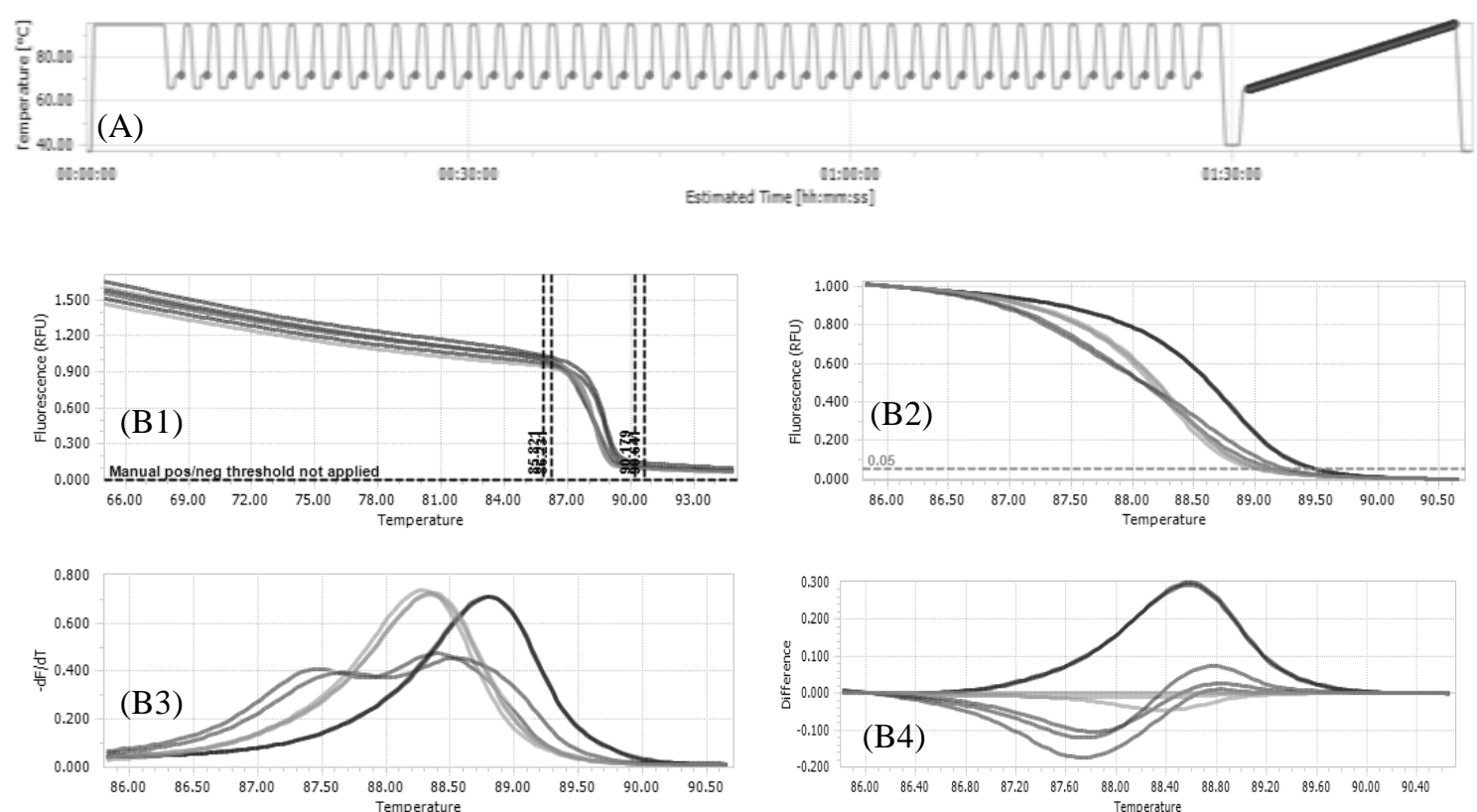

Figure 1. HRM principle and result visualization of three genotypes of a SNP. (A) Thermal setting-up of HRM analysis by LightCycler® 96 Real-time PCR system. (B1) Melting curves. (B2) Normalized melting curves. (B3) Melting peaks. (B4) Difference plots

\section{Genotyping and analysis}

The optimal HRM conditions were applied on 106 cases and 117 controls for genotyping. The reagents in one reaction consisted of Lightcycler 480 Resolight dye Mastermix 1X, $\mathrm{MgCl}_{2} 2.5 \mathrm{mM}$, HRM_Forward/Reverse primer $0.2 \mathrm{mM}$ and $45 \mathrm{ng}$ DNA sample. The setting-up of thermal cycles was the same as in the optimization step. In each running time, three positive controls and one negative control were included in the plate. The results were displayed using LightCycler® 96 SW 1.1 software. The abnormal-melting-curve samples and shiftedmelting-curve samples were subjected to be run again. The repeatedly failed samples were eliminated from analysis. The samples that exhibited identified genotype were then applied to calculate genotypic frequency to prepare for the analysis. As in analysis, Chi-squared test was applied using STATA.

\section{RESULT}

\section{Initial HRM conditions}

For the Ta optimization, the PCR reaction with gradient temperature ranged from 60 to 68 ${ }^{0} \mathrm{C}$ was run and the result was analyzed using gel electrophoresis. The reactions exhibited good amplification and no extra bands in all Ta (data not shown). The reactions with $\mathrm{Ta}$ in the range of 60-66 ${ }^{0} \mathrm{C}$, however, gave bolder and brighter band on the gel. As increasing $\mathrm{Ta}$, the specificity of primers is increased, so $66{ }^{0} \mathrm{C}$ was chosen as the Ta for further HRM analysis.

For the $\mathrm{MgCl}_{2}$ and DMSO concentration optimization, firstly the parameters that were predicted by using Umelt $\left(2 \mathrm{mM} \mathrm{Mg}^{2+}\right.$ and $10 \%$ DMSO) were applied to the HRM reaction. The result, however, failed to identify genotypes. To check what were the optimal concentrations of $\mathrm{MgCl}_{2}$ and DMSO, we had carried out several HRM reactions with different concentrations of DMSO and $\mathrm{MgCl}_{2}$. Finally $\mathrm{MgCl}_{2} 3 \mathrm{mM}$ was 
chosen as the initial condition for further screening and no DMSO was needed.

\section{Determination of three positive controls}

After obtaining HRM conditions for the first sample, it was proceeded to apply on 8 random samples in order to find out three distinct genotypes. Three groups of curves that could be assumed: 2 homozygote genotypes and a heterozygote genotype were obtained (Figure 2). The curves were well-separated into three groups of assumed genotype. Then selected samples, one from each group of curves was picked and sequenced to confirm the exact genotype of each sample.

Based on the sequencing result given in Figure 3, the homozygote AA was belong to the melting curve group which had a lower Tm of $88.4^{\circ} \mathrm{C}$, while homozygote $\mathrm{GG}$ had $\mathrm{Tm}$ of $88.8^{\circ} \mathrm{C}$. The sample melting at two different temperture showed two peaks $A$ and $G$ at the
SNP position which represented the heterozygote genotype (Figure 3C). Those three genotypedetermined samples were chosen to be three positive controls for later genotyping.

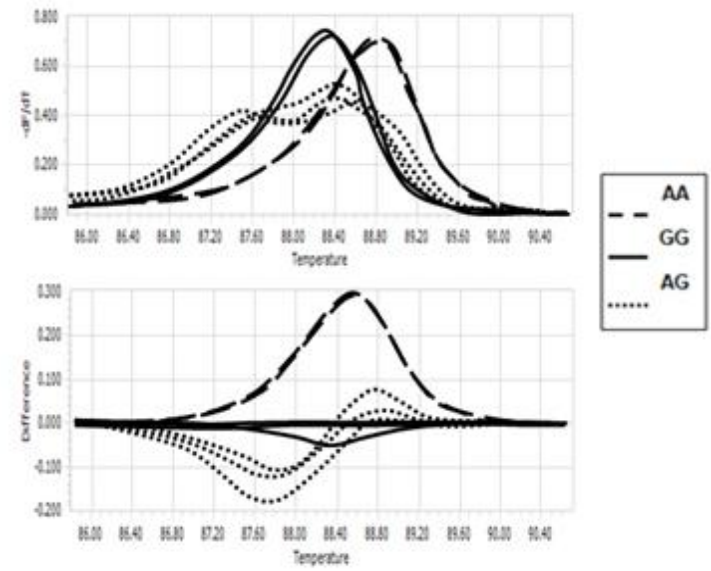

Figure 2. HRM analysis for 8 random samples. (A) Melting peaks. (B) Different plots

(A)
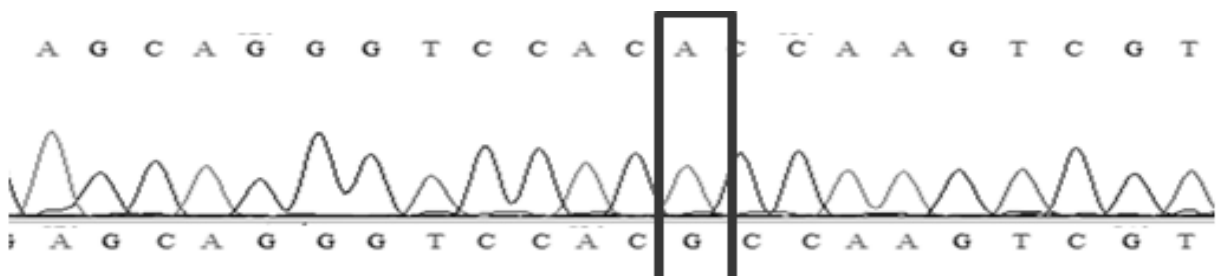

(B)

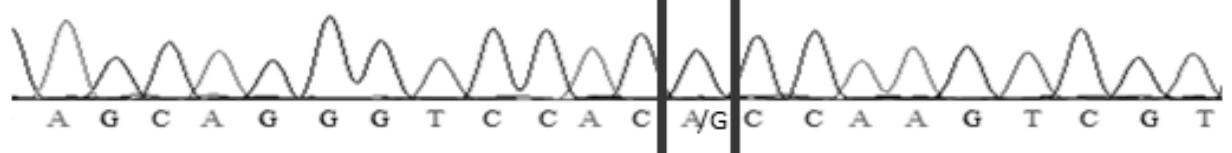

(C)

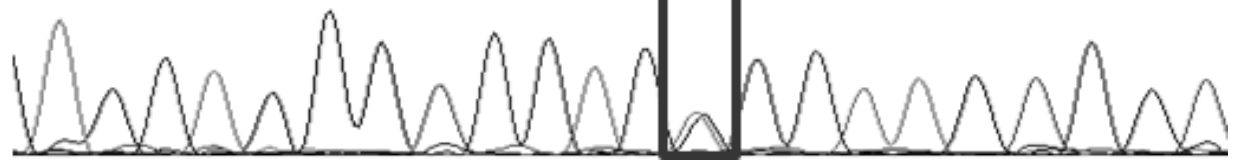

Figure 3. Sequencing results of three control samples. (A) Homozygote of A allele. (B) Homozygote of G allele. (C) Hetorozygote AG 


\section{Optimal the HRM protocol for genotyping}

As could be seen in Figure 2, the curves of three groups of genotype were not grouped very tightly together, especially heterozygote curves. On the other hand, 3 control samples for 3 genotypes have been determined, so it was decided to re-optimize the conditions with three controls to get a better condition for further analysis without confusing. Since $\mathrm{MgCl}_{2}$ was the component that might influence the organization of the melting curve between three genotypes, $\mathrm{MgCl}_{2}$ concentration was optimized again. HRM was run on three controls with different $\mathrm{MgCl}_{2}$ : $2.5 \mathrm{mM}, 3 \mathrm{mM}$ and $3.5 \mathrm{mM}$. The result revealed that at $\mathrm{MgCl}_{2} 2.5 \mathrm{mM}$, three melting curves exhibited the best shape and discrimination.

Afterward, we got the final optimal protocol for the HRM analysis of the SNP rs895819 which was given in Table 2 and 3.

Table 2. Thermal cycles of HRM analysis for genotyping SNP rs895819

\begin{tabular}{|c|c|}
\hline Thermal cycle steps & Temperature Duration \\
\hline 1. Preincubation & $95^{\circ} \mathrm{C}-300 \mathrm{~s}$ \\
\hline 2. Amplification & $\left.\begin{array}{l}95{ }^{0} \mathrm{C}-30 \mathrm{~s} \\
66{ }^{0} \mathrm{C}-15 \mathrm{~s} \\
72{ }^{0} \mathrm{C}-30 \mathrm{~s}\end{array}\right\} 40$ cycles \\
\hline \multirow{4}{*}{ 3. High resolution melting } & $95{ }^{0} \mathrm{C}-60 \mathrm{~s}$ \\
\hline & $40{ }^{0} \mathrm{C}-60 \mathrm{~s}$ \\
\hline & $65^{0} \mathrm{C}-30 \mathrm{~s}$ \\
\hline & $95^{0} \mathrm{C}-1 \mathrm{~s}$ \\
\hline 4. Cooling & $37^{0} \mathrm{C}-30 \mathrm{~s}$ \\
\hline
\end{tabular}

Table 3. Reagents of HRM analysis for genotyping SNP rs895819

\begin{tabular}{|l|l|}
\hline Reagents & Final concentration \\
\hline Master mix & $1 \mathrm{X}$ \\
\hline $\mathrm{MgCl}_{2}$ & $2.5 \mathrm{mM}$ \\
\hline DMSO & $0 \%$ \\
\hline DNA & $30 \mathrm{ng} / \mathrm{ul}$ \\
\hline Forward and Reverse primer & $0.2 \mu \mathrm{M}$ \\
\hline
\end{tabular}

\section{Genotyping and analysis}

After having all the optimal conditions for HRM analysis, it was applied to 106 cases and 117 controls. HRM was run several times, each time we performed 16-24 reactions, including three positive controls and one negative control. The HRM successful rate was $92 \%$. Most of reactions yielded good result in which the curves in one group clustered tightly to each other and well-separated with other groups (Figure 4).
Table 4 shows the detail genotyping as well as the analysis result of the SNP. Both case and control populations were in the Hardy Weinberg equilibrium. The Chi-squared test showed the p-value for allele difference between two populations was $\mathrm{P}=0.45413$, which was much higher than the threshold $(\mathrm{P}=0.05)$. Therefore, there was no significant association between this SNP and BC in Vietnamese population. 


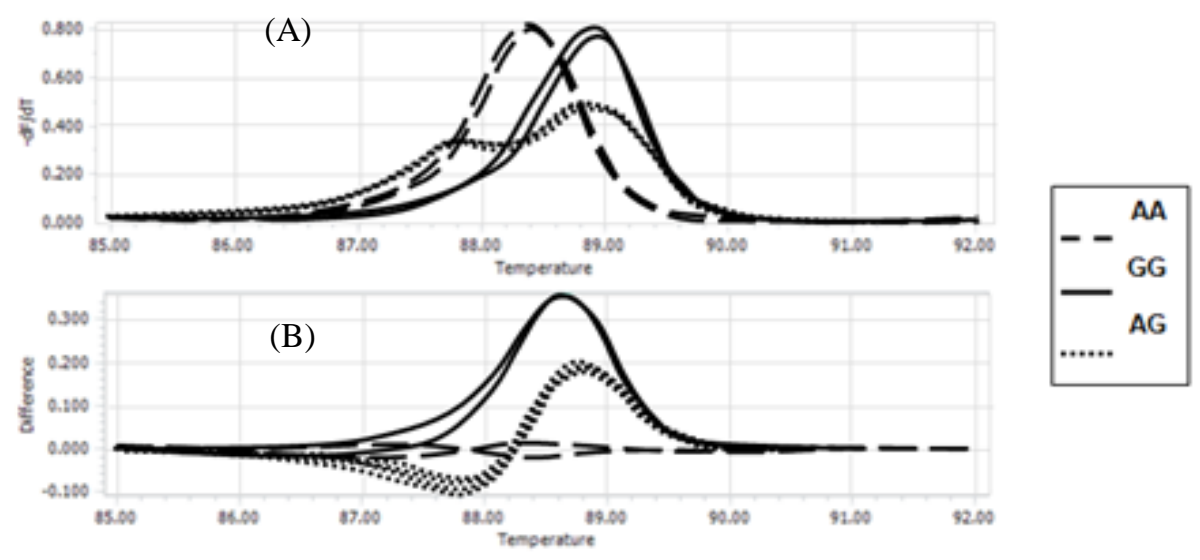

Figure 4. HRM analysis of 16 reactions (including positive and negative controls). (A) Melting peaks. (B) Different plots

Table 4. The detail genotyping and analysis result of SNP rs895819

\begin{tabular}{|l|c|c|c|c|c|}
\hline Genotypes & AA & AG & GG & A & G \\
\hline \multirow{2}{*}{ Cases (97) } & 40 & 45 & 12 & 125 & 69 \\
\cline { 2 - 6 } & $41.24 \%$ & $46.39 \%$ & $12.37 \%$ & $64.44 \%$ & $35.56 \%$ \\
\hline \multirow{2}{*}{ Controls (100) } & 49 & 38 & 13 & 136 & 64 \\
\cline { 2 - 6 } & $49.00 \%$ & $38.00 \%$ & $13.00 \%$ & $68.00 \%$ & $32.00 \%$ \\
\hline \multirow{2}{*}{ OR (CI 95 \%) } & & & & \multicolumn{2}{|c|}{$\begin{array}{c}1.173 \\
(0.772-1.782)\end{array}$} \\
\hline p-Value & & & & \multicolumn{2}{c|}{0.45413} \\
\hline
\end{tabular}

\section{DISCUSSION}

This study was carried out with the aim to examine the relationship of the SNP rs895819 with the aid of HRM analysis, a powerful molecular technique. In this study, a complete optimal HRM protocol was successfully developed to genotype the SNP in case-control samples. Compared to other techniques, HRM has some advantages such as the rapidity and high sensitivity. The sensitivity of HRM is the most important criterium. Even though the sequences are slightly different, the instrument can detect the difference and shows distinct curves. Furthermore, HRM is a single-step and closed-tube PCR, followed by a quick heating step and no requirement of gel electrophoresis for analysis as other technique such as Taqman genotyping or HPLC [13, 14]. In conclusion, the analysis result showed that the SNP rs895819 had no significant relationship with $\mathrm{BC}$ in Vietnamese population.

Previous studies had investigated the relationship of rs895819 with BC in different populations. One of the initial studies was conducted by Yang et al. in 2010. The study revealed that SNP rs895819 had a protective effect on the BC development in German women. The rare $\mathrm{G}$ allele of rs895819 was less common in the cases than in the controls, indicating a reduced familial breast cancer risk ([G] vs. [A]: $\mathrm{OR}=0.88,95 \%$ CI $0.78-0.99, \mathrm{P}=0.0287$ ) [9]. Later in 2013, Ning Zhang et al. [10] showed a similar result in which people with the $G$ allele exhibited a significantly decreased risk of $\mathrm{BC}$

\section{Trang 46}


relative to people carrying the A allele among the younger Chinese population ([G] vs. [A]: OR = $0.628,95 \%$ CI $0.410-0.961 ; \mathrm{P}=0.032)$. On the other hand, a study conducted in 2012 by Irene Catucci et al. [11] performed on Italian population revealed a contradictory result. They investigated the effect of rs895819 on BC risk by genotyping the 1,025 Italian familial BC cases and 1,593 controls. The result failed to support the relationship between of rs 895819 and the breast cancer risk ([G] vs. $[\mathrm{A}]$ : $\mathrm{OR}=0.91,95 \%$ CI $0.80-1.02, \mathrm{P}=0.114)$. The contradictory between those studies implies that although the SNP was proved to have a functional effect on its miRNA and (due to the effect of miR-27a to ER) the cancer development, the relationship between this SNP and the risk of BC is varied among different populations. This SNP might be a risk factor of BC in German and Chinese population but could not be proved to associate with the BC in the Vietnamese population.

The non-association of rs895819 in Vietnamese population can be explained by some reasons. The SNP may have a down regulation effect on miR-27a but this effect may be interrupted by activities of other SNPs located in this miRNA or protein ZBTB10 was downregulated by other SNPs or transcription factors, making the initiation of $\mathrm{BC}$ unchanged. In another scenario, this SNP may have significant effect on ER and through that inhibits the initiation of $\mathrm{BC}$ but it does not affect the risk of developing the disease because other SNPs or genetic factors may contribute to development of the disease.

This is the first time the SNP rs895819 was examined in the Vietnamese population using the novel HRM method. The method exhibited effectiveness in terms of sensitivity, specificity, task and time saving for the detection of genetic polymorphism. In the future, the protocol to genotype this SNP could be applied to any population is not only Vietnamese.

\section{CONCLUSION}

In conclusions, a HRM analysis was successfully developed for genotyping SNP rs895819. This method exhibited many advantages that make it become a potential choice for detecting genetic variants for diagnosis of diseases. This study also showed that in 97 breast cancer cases and 100 healthy samples the frequencies of $\mathrm{A}$ and $\mathrm{G}$ allele of rs895819 are $64.44 \%$ and $35.56 \%$ in the cases group; whereas in the control group, accounting for $68 \%$ and 32 $\%$, respectively. The SNP rs895819 in miR-27a was not associated with the breast cancer in the Vietnamese population $(\mathrm{OR}=1.173,95 \% \mathrm{CI}$ $0.772-1.782, \mathrm{P}=0.45413)$. In the future more SNPs need to be investigated in order to find out effective genetic markers for diagnosis of the breast cancer in Vietnamese.

Acknowledgement: This research is funded by Vietnam National Foundation for Science and Technology Development (NAFOSTED) under grant number 106-YS.01-2013.09. The authors thank to the Oncology Hospital - HCMC who supported for the sample collection. 


\section{Liên quan giữa SNP rs895819 $(\mathrm{A}>\mathrm{G})$ trên miR-27a và bệnh ung thư vú ở người Việt Nam}

- Nguyễn Bá Hùng Phong

- Trần Thị Hồng Minh

- Nguyễn Thị Ngọc Thanh

- Nguyễn Thị Huệ

Trường Đại học Khoa học Tự nhiên, ĐHQG-HCM

\section{TÓM TẮT}

Ung thu vú (UTV), loại ung thu phổ biến nhất ở phu nũ trên toàn thế giới, là bệnh di truyền gây ra bởi sư tuơng tác của nhiều gen khác nhau. Việc hiểu đurợc nhũ̃ng yếu tố di truyền liên quan đến UTV nhằm chẩn đoán sớm bệnh góp phần làm tăng khả năng sống sót của bệnh nhân. MicroRNA-27a (miR-27a), một miRNA gây ung thu, được dư đoán là có tác dụng trên ZBTB10, một phần tử ức chế khối u, nhằm điều hòa nhiều hoạt động chuyển hóa của tế bào. Điểm đa hình (SNP) rs895819 thay đổi cấu trúc và chức năng của miR-27a, điều này được chứng minh là làm giảm nguy co UTV ở một số quốc gia, thí dụ nhu Đức và Trung Quốc. Nghiên cứu này nhằm khảo sát mối liên quan giữa sụ hiện diện SNP rs895819 $(A>G)$ và UTV bằng cách sủ dụng phuoong pháp phân tích nhiệt độ nóng chảy

Tù̀ khoá: UTV, rs895819, phân tích độ nóng chảy, miR-27a

\section{REFERENCES}

[1]. American Cancer Society, Breast Cancer (2014).

[2]. P. Boyle, B. Levin, World cancer report, (2008).

[3]. IARC. GLOBALCAN 2012: Estimated cancer incidence, mortality and prevalence worldwide (2012).

[4]. N.B. Duc, Epidemiology and program of control and prevention for cancer: preliminary report of national cancer project period 2008-2010, Viet J. Oncol., 2, 21-31 (2010).
(High Resolution Melting). 106 mẫu DNA UTV và 117 mẫu DNA khỏe manh được xác định kiểu gen bằng phương pháp HRM đã tối uu hóa sau đó phân tích thống kê được áp dụng để kiểm tra mối liên quan giữa SNP và UTV. Allek $G$ chiếm $36 \%$ trong nhóm bệnh UTV và $32 \%$ trong nhóm khỏe mạn. Kết quả thống kê cho thấy rằng rs895819 (A> G) không có liên quan đáng kể đến ung thu vú $(O R=1,119 ; P=0,46676)$. Mặc dù SNP này có liên quan đáng kể đến UTV của nguời Đức và Trung Quốc, nhưng không phải là một dấu ấn sinh học tiềm năng để chẩn đoán UTV ở ngườ Việt Nam. Trong tuoong lai, các SNP khác cần được nghiên cứu để xác định các dấu ấn sinh học tiềm năng trong chẩn đoán sớm UTV ở người Việt Nam.
[5]. D.P. Bartel, MicroRNAs: genomics, biogenesis, mechanism, and function, Cell, 116, 2, 281-97 (2004).

[6]. X. Li, et al., MicroRNA-27a Indirectly regulates estrogen receptor \{alpha\} expression and hormone responsiveness in MCF-7 breast cancer cells, Endocrinology, 151, 6, 2462-73 (2010).

[7]. S.U. Mertens-Talcott, et al., The oncogenic microRNA-27a targets genes that regulate specificity protein transcription factors and the G2-M checkpoint in MDA-MB-231

\section{Trang 48}


breast cancer cells, Cancer Res., 67, 22, 11001-11 (2007).

[8]. W. Tang, et al., MiR-27 as a prognostic marker for breast cancer progression and patient survival, PLoS One, 7, 12, e51702 (2012).

[9]. R. Yang, et al., A genetic variant in the premiR-27a oncogene is associated with a reduced familial breast cancer risk, Breast Cancer Research and Treatment, 121, 3, 693-702 (2010).

[10]. N. Zhang, et al., A genetic variant in premiR-27a is associated with a reduced breast cancer risk in younger Chinese population, Gene, 529, 1, 125-30 (2013).

[11]. I. Catucci, et al., The SNP rs895819 in miR-
$27 \mathrm{a}$ is not associated with familial breast cancer risk in Italians, Breast Cancer Res Treat, 133, 2, 805-7 (2012).

[12]. N.T. Hue, et al., Extraction of human genomic DNA from dried blood spots and hair roots, $I J B B B, 2,1,21-26$ (2012).

[13]. M. Liew, et al., Genotyping of singlenucleotide polymorphisms by highresolution melting of small amplicons, Clin Chem, 50, 7, 1156-64 (2004).

[14]. R.H. Vossen, et al., High-resolution melting analysis (HRMA): more than just sequence variant screening, Hum Mutat, 30, 6, 860-6 (2009). 